\title{
Retraction Note to: Aging-related tumor associated fibroblasts changes could worsen the prognosis of GBM patients
}

Hongwang Song ${ }^{1 *+}$, Xiaojun $\mathrm{Fu}^{2^{*+}} \odot$, Chenxing $\mathrm{Wu}^{2}$ and Shouwei $\mathrm{Li}^{2}$

\section{Retraction Note to : Cancer Cell Int (2020) 20:489 https://doi.org/10.1186/s12935-020-01571-7}

The Editors-in-Chief have retracted this article because there appear to be image duplications in the Vimentin, CD44 and E-cadherin rows of Fig. 8F. The Editors-inChief therefore no longer have confidence in the integrity of the data in this article [1].

Xiaojun $\mathrm{Fu}$ does not agree to this retraction. Hongwang Song, Chenxing Wu and Shouwei Li have not responded to any correspondence from the publisher about this retraction.

Published online: 09 April 2021

\section{Reference}

1. Song H, Fu X, Wu C, Li S. Aging-related tumor associated fibroblasts changes could worsen the prognosis of GBM patients. Cancer Cell Int. 2020;20:489. https://doi.org/10.1186/s12935-020-01571-7.

\section{Publisher's Note}

Springer Nature remains neutral with regard to jurisdictional claims in published maps and institutional affiliations.

(c) The Author(s) 2021. This article is licensed under a Creative Commons Attribution 4.0 International License, which permits use, sharing, adaptation, distribution and reproduction in any medium or format, as long as you give appropriate credit to the original author(s) and the source, provide a link to the Creative Commons licence, and indicate if changes were made. The images or other third party material in this article are included in the article's Creative Commons licence, unless indicated otherwise in a credit line to the material. If material is not included in the article's Creative Commons licence and your intended use is not permitted by statutory regulation or exceeds the permitted use, you will need to obtain permission directly from the copyright holder. To view a copy of this licence, visit http://creativecommons.org/licenses/by/4.0/. The Creative Commons Public Domain Dedication waiver (http://creativecommons.org/publicdomain/zero/1.0/) applies to the data made available in this article, unless otherwise stated in a credit line to the data. 